\title{
A HISTORICAL ANALYSIS OF CENTRAL BANK INDEPENDENCE IN LATIN AMERICA: THE COLOMBIAN EXPERIENCE, 1923-2008*
}

\author{
ADOLFO MEISEL \\ Banco de la República (Central Bank of Colombia) ${ }^{a}$ \\ JUAN D. BARÓN \\ Banco de la República (Central Bank of Colombia)
}

\begin{abstract}
This paper explores the relationship between central bank independence and inflation in Latin America, using the experience of Colombia (1923-2008) as a case study. Since its creation, in 1923, Colombia's central bank has undergone several reforms that have changed its objectives and degree of independence. Between 1923 and 1951, it was private and independent, with a legal commitment to price stability. In 1962, monetary responsibilities were divided between a government-dominated monetary board, in charge of monetary policies, and the central bank, which carried them out. In the early 1990s, the bank recovered its independence and its focus on price stability. Inflation varied substantially during these subperiods. Our analysis suggests
\end{abstract}

* Received 26 September 2009. Accepted 17 November 2009. We thank Haroldo Calvo, Hernando Vargas, and three anonymous referees for comments and suggestions to previous versions of this document. Leidy Laura Rueda provided outstanding research assistance. The findings and views reported in this article are those of the authors and should not be attributed to the Banco de la República (Central Bank of Colombia) or its Board of Directors.

a Centro de Estudios Económicos Regionales. Banco de la República. Calle 33 \# 3 - 123 (Centro). Cartagena de Indias. Colombia. ameisero@banrep.gov.co, jbaronri@banrep.gov.co 
that the central bank independence, combined with a commitment to price stability, renders the best results in terms of price stability.

Keywords: inflation, central bank, independence, Latin America, Colombia

JEL Code: N16, N26

\section{RESUMEN}

Este documento explora la relación entre la independencia del banco central y los niveles de inflación en Latinoamérica, usando como estudio de caso la experiencia de Colombia (1923-2008). Desde su creación en 1923, la independencia y objetivos del banco central en Colombia han sido modificados substancialmente. Entre 1923 y 1951, el banco central fue privado e independiente, y con objetivo principal la estabilidad de precios. En 1962, la responsabilidad monetaria fue dividida entre la Junta Monetaria, encargada del diseño de la política monetaria, y el banco central, que se encargaba de ejecutarla. A principios de los 1990s, el banco recobró su independencia y su objetivo fue el control de la inflación. Los niveles de inflación fueron diferentes en estos periodos. El análisis sugiere que la combinación entre un banco central independiente y un objetivo de estabilidad de precios produce los mejores resultados en términos de estabilización de precios.

Palabras clave: inflación, independencia, banco central, Latinoamérica, Colombia

\section{INTRODUCTION}

In this paper, we study the relationship between the institutional reforms that the Colombian central bank, Banco de la República, has undergone since its creation in 1923 and the level and variability of the country's rate of inflation. Over the past decade, there has been an abundant empirical literature on the relationship between central bank independence and inflation. This body of literature, however, usually employs cross-section statistical analysis. Thus, there are important country-specific characteristics that have not been taken into consideration. For this reason, it is fruitful to examine country-specific historical experiences in depth. Colombia is an interesting case study in this respect, since its central bank is one of the two oldest banks in Latin America and has experienced distinct subperiods in which its objectives and degree of autonomy have varied. Recently, it has been argued that the central bank has seen its real independence reduced, as a result of the introduction of the re-election of the President of the Republic in 2006. 
Our analysis finds that the central bank has operated under different degrees of autonomy and different mandates in its almost 90 years of history. Each of these institutional arrangements has resulted in different outcomes in terms of price variability. The best, in terms of low inflation, coincided with the latest period (1992-2008) in which the central bank's mandate was to protect the purchasing parity of the currency and it was made independent to achieve that goal.

In the next section, we review the recent empirical literature on the relationship between central bank independence and inflation. We then present the Colombian case. In the fourth section, we discuss whether there was a structural break in the inflation rate in the early 1990s as a result of the change in central bank legislation ushered by the Constitution of 1991. Finally, we present some conclusions.

\section{A REVIEW OF THE LITERATURE}

In 1973, with the generalized increase in inflation after the end of the Bretton Woods agreements, under which fixed exchange rates worked as nominal anchors, several proposals to achieve price stability were put forward. One of the first came from Milton Friedman. Friedman argued that price stability could be achieved by allowing central banks to pursue a monetary policy based on a fixed rule announced every year. It can be shown, however, that commitment to such a rule is not an optimal strategy because it makes central banks too inflexible to deal with unanticipated shocks, particularly on the supply side (Rogoff 1985).

In 1976, Hayek (1976) proposed a more radical strategy to achieve price stability. His argument was based on the denationalization of money, and his core idea was that private banks should issue their own currencies - currencies that were not convertible against each other. Under this proposal, banks would have the incentive to obtain funds from consumers at no cost by encouraging them to hold their own currency. This is known as a "free-banking» regime.

As a result of Hayek's «eccentric» proposal, interest increased in the study of the historical experience with free banking. Under the free-banking system, there are no barriers to entry and there is no centralized control of international reserves (Schuler 1992). The arrangement existed in many countries before the consolidation of a system with a central bank with a monopoly on the issuance of currency.

Traditional economic historiography, particularly in the United States, took a strong negative view of the experience with free banking, given that this system was said to "overprint» money. According to this view, freebanking regimes would inevitably end in massive withdrawals of deposits and banking panics. More recently, research by economic historians, such as Rockoff (1974), Rolnick and Weber (1983) and White (1984) has contributed 
to the analysis of a wide variety of international historical experiences with free banking. These authors found that free-banking regimes were generally successful in achieving price stability.

Despite the historical evidence supporting the success of free banking in achieving price stability, it has very few supporters at present. The problem is that it is unclear how a system of free banking can be introduced without going back to a gold or silver standard. Thus, at present, the attractiveness of the free-banking system is very limited (Sechrest 1993).

A less radical approach to achieve price stability is that which postulates an autonomous central bank. In fact, since the 1980s, this idea has gained support (Cukierman 2008). Part of this support stems from the success of the Bundesbank (one of the most autonomous central banks in the world) in achieving a relatively low rate of inflation for several decades. For the period 1970-1990, the average inflation rate in the Federal Republic of Germany was 3.8 per cent, the lowest among the main economies of the world.

How does the central bank independence yield lower inflation rates? There are at least three mechanisms. First, some authors who hold the "public choice view», such as Buchanan and Wagner, argue that without independence, there is strong pressure on the central bank to behave in line with the preferences of the government. As Buchanan and Wagner put it,

A monetary decision maker is in a position only one stage removed from that of the directly elected politician. He will normally have been appointed to office by a politician subject to electoral testing, and he may even serve at the pleasure of the latter. It is scarcely to be expected that persons who are chosen as monetary decision makers will be the sort that are likely to take policy stances sharply contrary to those desired by their political associates, especially since these stances would also run counter to strong public opinion and media pressures ... 'Easy money' is also 'easy' for the monetary manager ... (de Haan and Sturm 1992).

A second mechanism through which greater central bank independence yields lower inflation is that governments with discretional powers over monetary policy have the incentive to follow an expansionist path to achieve short-term reductions in unemployment. As this instrument is used more and more often, feeding price-rise expectations, inflation increases without having any effect on employment. For this reason, an autonomous central bank will achieve lower inflation in this context without affecting the real sector of the economy.

The third mechanism is suggested by Sargent and Wallace (1981), who point out that when fiscal policy is dominant - that is, when the central bank cannot influence the size of the fiscal deficit - money supply becomes endogenous. If, on the other hand, monetary policy is the dominant policy, fiscal authorities will be forced to reduce the fiscal deficit. 
Perhaps the idea of central bank independence owes its current popularity more to the international empirical evidence concerning its positive effects than to the theoretical arguments. In fact, since the pioneering work of Bade and Parkin (1985), several other studies have found statistical evidence consistent with the hypothesis of an inverse relationship between the degree of central bank independence and the inflation rate (Alesina $1988)^{1}$.

One of the first studies to analyze the relationship between central bank independence and price stability is that of Bade and Parkin (1985), who examine the experiences of twelve developed countries in the period after Bretton Woods. They constructed a measure of central bank independence that takes a value of one, when independence is at the minimal level, and four, when independence is at the highest. The results show that the degree of independence, as measured by their index, is an important factor for determining the level of inflation, and that the two countries with the highest central bank independence in the sample (Germany and Switzerland) had inflation rates below the average for the sample. On the other hand, they found no differences in the inflation rates of countries whose central banks were classified as less independent. Alesina (1988) adds four more countries (Denmark, New Zealand, Norway and Spain) to the Bade and Parkin sample, and shows that there is an inverse relationship between the degree of independence of the central bank and the average inflation level in the period 1973-1985.

Other studies using different types of independence index also find evidence consistent with these results. Grilli et al. (1991), for example, develop two types of index to capture different facets of central bank independence: one measures economic independence and the other, political independence. In their regression analysis of inflation, they used data for the period 19501989 and a sample of eighteen developed countries. They found that central bank independence indexes always have the correct sign (negative). In addition, the coefficient of the economic independence of the central bank is statistically significant in periods of high inflation, and the political independence index is statistically significant in the 1970s. Although not conclusive, these results are indicative of a potential association between the central bank independence and inflation.

Despite the evidence presented by these early studies, it was not clear how robust these results would be with a more representative sample of countries, and, in particular, how these results would change with the inclusion of developing countries. Cukierman et al. (1992) partially addressed both these concerns by using a sample of seventy-two countries, of which fifty-one were developing nations. Their results were consistent with the earlier literature in

1 See Eijffinger and de Haan (1996), Berger et al. (2001) and Cukierman (2008) for thorough reviews of the literature on the central bank independence. 
that they found a negative correlation between the central bank independence and inflation. This result, however, is only found for the industrialized countries in their sample. The authors argued that, in developing countries, «formal» central bank independence can differ from "actual» independence. For this reason, they use indicators of real independence, such as the political vulnerability of the central bank governor, as measured by the probability of a change of governor giving a change in the government. As expected, they find a statistically positive relationship between inflation and the political vulnerability of the central bank governor. Since these authors find that for developing countries there is Granger causality in both directions between inflation and the vulnerability of the central bank governor, the role of autonomy in shaping inflation is not as clear as for the subsample of developed countries.

The main characteristic of the studies described above is that they use cross-section analysis. It is very unlikely that the correlations thus estimated reflect the true interrelation between the autonomy of the central bank and the dynamics of inflation. Alesina (1988), for example, points out that this correlation can arise because countries that prefer low inflation may also prefer independent central banks. In other words, there might be some unobserved characteristics correlated with central bank independence that, if not controlled for in the regressions, will cause the coefficient on independence to be biased. In a recent study, Crowe and Meade (2008), using longitudinal data to eliminate country-fixed effects and using their own measure of central bank independence, find evidence of an inverse relation between independence of the central bank and inflation ${ }^{2}$. This implies that, even when controlling for country heterogeneity and shocks that affect all countries simultaneously, the inverse relation between central bank independence and inflation still persists.

For the specific case of Latin America, Jácome and Vázquez (2008) have produced what is perhaps the most complete empirical analysis of the relationship between the central bank independence and inflation. Their study uses data for twenty-four countries in the period 1985-2002. The authors use longitudinal information and panel data methods to overcome some of the limitations of the earlier studies. In particular, they are able to account for time-invariant variables related to inflation and to take into account shocks that affect all countries in the same year (e.g. the reforms of the 1990s). They find that, on average, countries with more independent central banks (as measured by four indicators of legal and actual independence) have lower inflation rates during the period. This finding is in sharp contrast with earlier studies, such as de Hann and Kooi (2000) and Jácome (2001), which were unable to find a strong relationship between these two variables in the case of

2 This study also calculates measures of the central bank transparency and relates them to inflation rates. 
developing countries ${ }^{3}$. Studies using alternative measures of the central bank independence (e.g whether countries include legal independence in the constitution) also found a negative correlation with inflation, perhaps because this measure captures commitment with price stability more successfully and because constitutional measures are more likely to be enforced and implemented (Gutiérrez 2003) .

Despite the recent focus of the literature on panel data methods and cross-country regressions, other authors take a different empirical approach by focusing on the experience of particular countries ${ }^{5}$. For example, Otero and Ramírez (2006) use a pure time-series model of the determinants of inflation to test statistically whether the reform of the independence of the central bank in the early 1990s in Colombia changed the parameters of the model. They found that both internal and external factors are important in explaining the inflation rate (at least in the Colombian case), and that re-establishing the independence of the central bank changes the parameters of the model. In particular, they found that disequilibria in the goods and money markets had a larger effect on inflation before the central bank was made independent in $1991^{6}$.

An alternative approach for the analysis of the relationship between the independence of the central bank and price stability is a careful review of country cases. One advantage of case studies is the possibility of carrying out deeper analysis over a relatively longer period of time and taking advantage of changes in the degree of autonomy of the central bank over time. Colombia is an interesting case in this respect because, since its creation in 1923, the central bank has acted under different degrees of independence.

\section{THE CASE OF COLOMBIA, 1923-2008}

Colombia has one the most varied experiences with central banking in Latin America, since it was the second country in the region to establish such

${ }^{3}$ Some papers also find no evidence of a relationship between the central bank independence and inflation in industrialized countries. Daunfeldt and De Luna (2008), for example, find that price stability is achieved before more independence is given to central banks in OECD countries.

${ }^{4}$ For an analysis of the reforms that lead to the creation of the independent central banks in Latin America, see Bonnet and Vargas (1994), Carstens and Jácome (2005) and Jácome (2008).

${ }^{5}$ For the Colombian experience, see Echeverri (1991), Meisel (1992), Restrepo (2000), Kalmanovitz (2003) and Giraldo Palomino (2007).

${ }^{6}$ In terms of the legal independence of the central bank in Colombia, one important question is how the legal powers given to the central bank in the early 1990s are compared to the legal framework of successful central banks in other countries. Gómez Mejía (1997) undertakes a comparative analysis of the laws determining the central bank independence in several countries. He finds that the legal structure that defined the central bank in Colombia is similar to that of successful European central banks, and concludes that, at least in theory, this gives the central bank in Colombia a good chance of succeeding in controlling inflation. 
TABLE 1

MAIN SUBPERIODS IN THE INSTITUTIONAL HISTORY OF THE COLOMBIAN CENTRAL BANK (1923 TO PRESENT)

\begin{tabular}{|l|c|c|c|c|}
\hline Period & $\begin{array}{c}\text { Name of the } \\
\text { central bank }\end{array}$ & Nature & Main objective & $\begin{array}{c}\text { Commitment to } \\
\text { price stability? }\end{array}$ \\
\hline $1923-1951$ & $\begin{array}{c}\text { Banco de la } \\
\text { República }\end{array}$ & $\begin{array}{l}\text { Private and } \\
\text { autonomous }\end{array}$ & Price stability & Yes \\
\hline $1952-1963$ & $\begin{array}{c}\text { Banco de la } \\
\text { República }\end{array}$ & $\begin{array}{c}\text { Private and } \\
\text { autonomous }\end{array}$ & $\begin{array}{c}\text { Price stability } \\
\text { and «rapid } \\
\text { economic } \\
\text { development» }\end{array}$ & No \\
\hline $1964-1991$ & $\begin{array}{c}\text { Junta } \\
\text { Monetaria }\end{array}$ & $\begin{array}{c}\text { State-owned } \\
\text { with no } \\
\text { autonomy }\end{array}$ & $\begin{array}{c}\text { Management of } \\
\text { monetary, } \\
\text { exchange rate } \\
\text { and credit } \\
\text { policies }\end{array}$ & No \\
\hline 1992 -present & $\begin{array}{c}\text { Banco de la } \\
\text { República }\end{array}$ & $\begin{array}{c}\text { State-owned } \\
\text { and } \\
\text { autonomous }\end{array}$ & $\begin{array}{c}\text { Price stability } \\
\text { Yes }\end{array}$ & \\
\hline
\end{tabular}

an institution ${ }^{7}$. In addition, since its creation in 1923, under the direction of the American advisor, Edwin W. Kemmerer, the Banco de la República has undergone several major reforms that seem to have influenced the degree of its autonomy vis-'a-vis the central government. Thus, it is an ideal case to study the interrelationships between the degree of central bank independence and the level and variability of the rate of inflation.

To establish the main subperiods in the history of the Banco de la República, two aspects were taken into consideration: whether formal autonomy was existed and the main objectives were established for the central bank by law. Note that we explicitly avoided using the behavior of inflation to define the subperiods. Using the above two criteria, it is possible to identify four subperiods (see Table 1). Figure 1 presents the evolution of inflation since the creation of the central bank in 1923 and shows the four subperiods.

When the Colombian central bank was created in 1923, a clear commitment with the stability of the purchasing power of the peso convertible to gold and the smooth functioning of the gold standard was established by law. To further maintain this commitment, it was determined that the institution would be a private bank, with the government among its stockholders. At this time, many other countries were establishing independent central banks,

7 For an analysis of the development and evolution of the Colombian financial system during the $20^{\text {th }}$ century, see Urrutia Montoya and Caballero Argáez (2006). 
FIGURE 1

INFLATION RATE IN COLOMBIA (1923-2008)

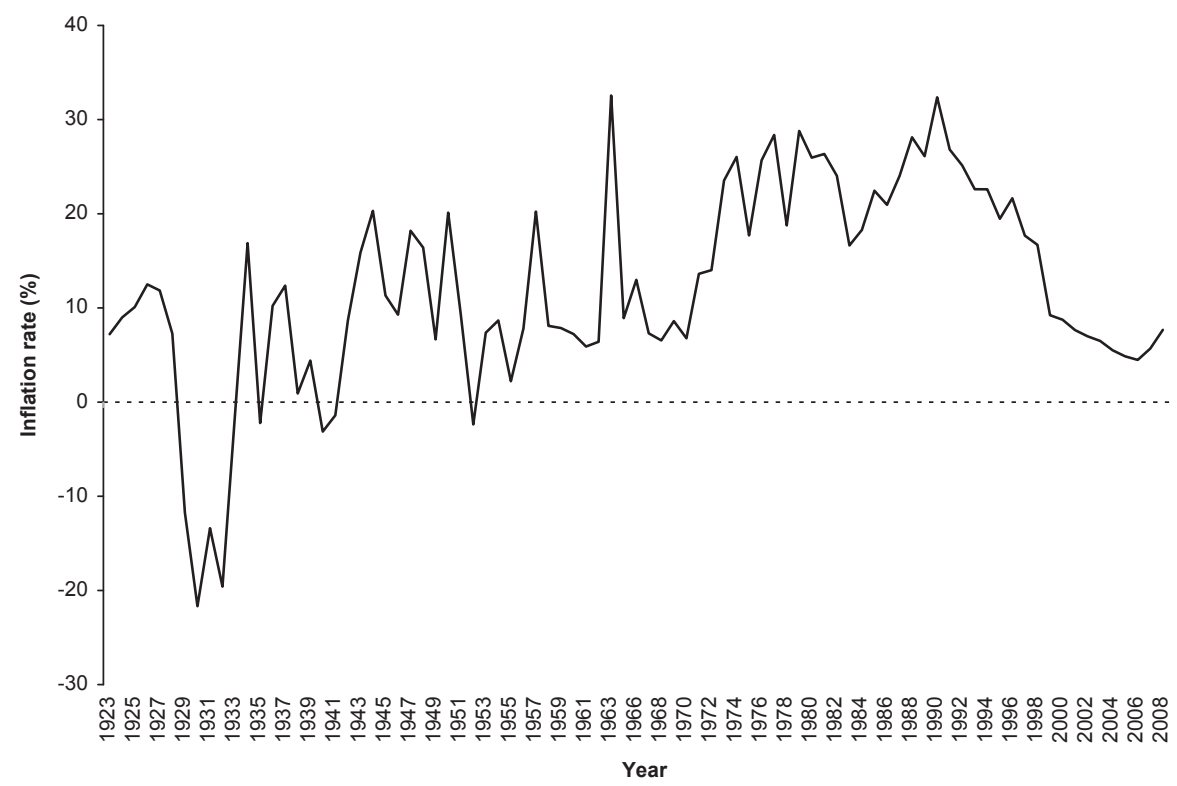

Sources: Grupo de Estudios de Crecimiento Económico, GRECO, (1999) and data from the Banco de la República website (www.banrep.gov.co).

Note: The vertical lines coincide with the years of major reforms to the autonomy of the central bank.

and the most influential academic economists were also promoting them. For example, at the International Conference of Finance, held in Brussels in 1920, a call was made for every country to create an autonomous central bank (Deane and Pringle 1994).

In Colombia, the gold standard was maintained until 1931. Subsequently, the nominal exchange was kept fixed, except in the period 1933-1935, when the peso was devalued with respect to the U.S. dollar. Thus, during the period 1923-1951, the money supply was endogenous and the level of inflation was determined by the level of inflation of the main trading partners, basically the United States. Thus, the correlation coefficient between the level of inflation in Colombia and the United States for this first subperiod was 62 per cent.

It can be said that the central bank autonomy and the commitment to price stability in the period 1923-1951 produced a relatively low-average yearly rate of inflation (5.6 per cent). However, the variability of the inflation rate, as measured by the standard deviation around the linear trend, was the highest among the four subperiods that we are discussing (see Table 2). 
TABLE 2

SOME MONETARY INDICATORS FOR THE MAIN SUBPERIODS IN THE HISTORY OF THE COLOMBIAN CENTRAL BANK

\begin{tabular}{|c|c|c|c|c|}
\hline Period & $\begin{array}{c}\text { Inflation rate } \\
\text { (mean) }\end{array}$ & $\begin{array}{c}\text { Coefficient on } \\
\text { trend }^{(a)}\end{array}$ & $\begin{array}{c}\text { Standard } \\
\text { deviation around } \\
\text { linear trend }^{(b)}\end{array}$ & $\begin{array}{c}\text { Was inflation } \\
\text { higher than in the } \\
\text { previous period? }\end{array}$ \\
\hline $1923-1951$ & 5.6 & $0.49(0.23)$ & 10.4 & \\
\hline $1952-1963$ & 9.3 & $1.29(0.67)$ & 7.6 & Yes \\
\hline 1964-1991 & 19.8 & $0.71(0.12)$ & 5.0 & Yes \\
\hline $1992-2008$ & 12.5 & $-1.37(0.15)$ & 2.9 & No \\
\hline
\end{tabular}

(a) This figure is the coefficient on a linear trend that comes from an ordinary least squares (OLS) regression of inflation on a constant and a linear trend. The numbers in parentheses are standard errors.

(b) This is the standard deviation of the residuals from an OLS regression of inflation on a constant and a linear trend.

As the money supply was endogenous and the inflation rate depended on the international rate of inflation, the explanation for the enormous variability of its level is found in events related to the world economy: the Great Depression and the reduction of inflation it produced, and World War II, which in Colombia generated price rises because of lower imports of key supplies, which in turn led to an enormous increase in international reserves.

Beginning in the late 1940s, there was broad discussion in Colombia concerning different proposals to reform the central bank. One of the issues most often raised was the credit policy, which was seen as too orthodox. Some of the promoters of the reform wanted the Banco de la República to play an active role in economic development through the granting of longterm subsidized credit. With this intention, in 1949, the government invited Richard Grove and Gerald Alter, of the Federal Reserve Bank, to study the Colombian financial system and recommend changes. Their proposals were presented in two documents written in 1950 (Grove and Alter 1986a, b). The main aspects of what they proposed were included in Decree 756 of 1951, which redefined the instruments at the disposal of the central bank as well as its objectives. In its first article, this decree was very clear about the new perspective that would guide the central bank: «... the Banco de la República will carry out a monetary, credit, and exchange rate policy oriented toward stimulating the conditions for the accelerated development of the Colombian economy.» As a result of the changes in the central bank legislation carried through in 1951, subsidized credit, crédito de fomento, increased from 7.6 per cent of the total credit in 1952 to 15.0 per cent by 1960 .

The new economic philosophy, which had started to dominate monetary policy in the early 1950s, led to a reduction in price stability. However, since there were still fixed exchange rates, monetary expansion led to cycles of 
price increase, revaluation of the peso vs. the U.S. dollar, and, eventually, to a devaluation of the nominal exchange rate. This is why the period is known in Colombian macroeconomic history as that of «stop-go» policies. Thus, it can be said that the period 1951-1963 was very unstable from a macroeconomic point of view - inflation almost doubled and its deviation from the trend was also high (see Table 2).

Beginning in the 1940s, it was often argued that it was inappropriate for the Banco de la República to be a private bank. Finally, in 1962, a way around the private nature of the central bank, similar to steps taken in Paraguay (1944), Guatemala (1945) and Ecuador (1948), was proposed: the creation of a government-controlled monetary board (Junta Monetaria). As a result, since 1963, the Colombian central bank has been divided between a monetary board, which determined monetary, credit and exchange rate policies, and the Banco de la República, which implemented these policies.

The monetary board never had a clear commitment to the stability of the purchasing power of the peso. In this respect, the Minister of Finance at the time was very clear about the consequences of the lack of autonomy of the monetary board with respect to the government:

If governments are bad, there will be bad monetary management, and a bad and difficult situation for the country. If governments are good, the situation will improve for the country. But it is the state, represented by the government, that ought to direct monetary policy (Sanz de Santamaría 1965, p. 228).

A possible consequence of the loss of central bank autonomy was a significant increase in the average level of inflation, which rose to an annual rate of 19.8 per cent, during the period 1964-1991. Although the variability of the average inflation rate fell with respect to the earlier period, it was still high. This reduction could perhaps be explained by the adoption of a crawling peg regime in 1967, which eliminated the abrupt devaluations of the period 1952-1963 and the stop-go macroeconomic cycles (Figures 2 and 3).

In 1991, Colombia approved a new constitution. One of the most important economic reforms it brought about was the re-establishment of the central bank autonomy. The monetary board was abolished and the Banco de la República regained the control of monetary and credit policy. Since, in 1973, it had been converted into a government bank (the government became the controlling stockholder), this reform did not simply represent a return to the situation of the period 1923-1951. Now, the Banco de la República also controlled all aspects of exchange rate policy, an important aspect of economic policy, which, before 1991, had been in the hands of Congress.

Law 31 of 1992, which developed the new constitutional obligations of the central bank, established very clearly that its main goal was to maintain the purchasing power of the peso. To assure the independence of the Banco de la 
FIGURE 2

INSTITUTIONAL DETERMINANTS OF INFLATION

Central bank's objective

\begin{tabular}{|c|c|c|}
\hline & Orthodox & Unorthodox \\
\hline $\begin{array}{l}\frac{c}{0} \\
\frac{0}{0} \\
\frac{c}{0} \\
\frac{0}{0} \\
\underline{0} \\
\underline{\Xi}\end{array}$ & $\begin{array}{c}\text { (1) } \\
\text { Minimum } \\
\text { inflation }\end{array}$ & $\begin{array}{l}\text { (3) } \\
\text { Intermediate to high } \\
\text { inflation }\end{array}$ \\
\hline $\begin{array}{l}\text { t̃ } \\
\frac{0}{0} \\
\frac{0}{0} \\
\frac{0}{0}\end{array}$ & $\begin{array}{l}\text { (2) } \\
\begin{array}{l}\text { Intermediate to low } \\
\text { inflation }\end{array}\end{array}$ & $\begin{array}{c}(4) \\
\text { Maximum } \\
\text { inflation }\end{array}$ \\
\hline
\end{tabular}

FIGURE 3

INSTITUTIONAL DETERMINANTS OF INFLATION AND THE COLOMBIAN EXPERIENCE (1923-2008)

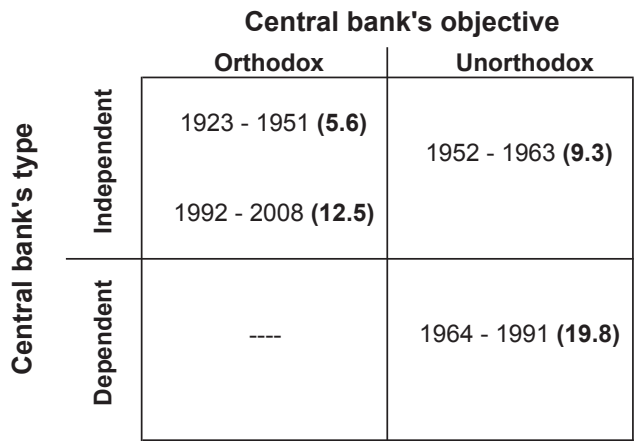

Note: The numbers in parentheses refer to the average inflation rate during the period.

República, the law also determined that each President of Colombia, midway through his term of office, would appoint two of the five members of the board of directors. These members are appointed for successive periods of 4 years and can stay in office for a maximum of three periods (12 years). In turn, the members of the board of directors, in conjunction with the Minister of Finance (who presides the board) appoint the general manager (President) for a period of 4 years. The general manager may be re-elected for a maximum of two periods.

The complete board of directors of the Banco de la República is composed of the five members, plus the Minister of Finance and the general manager. 
Thus, theoretically, of the seven members, each President would appoint a maximum of three, but for two of them, the appointment only coincides with the last 2 years of that presidential period. However, since 1991, presidents have appointed at least three members of the board (in addition to the Minister), because it has been common for board members to resign before the end of the 4-year period. In addition, in 2006, the Constitution was changed to allow for the re-election of the President of the Republic. Thus, a re-elected President, as has happened with Alvaro Uribe in the period 20062010, appoints at least four board members plus the Minister, which leads to a clear majority. For this reason, some critics argue that presidential reelection has weakened the autonomy of the central bank. Others, nevertheless, argue that the constitutional mandate of the central bank to preserve the purchasing power of the currency is so clear that it does not matter that one president may eventually appoint a majority of the board members. Finally, others believe that this will depend to a great extent on the quality of the appointees. If, as has happened until now, high-level professional economists are named, the independence of the bank will be preserved. This situation, however, does not prevent the possibility that if politically motivated designations predominate, things could be different and the central bank could fall under the complete control of the government in office. In sum, presidential re-election has potentially reduced the autonomy of the central bank ${ }^{8}$.

Despite this apparent reduction in the independence of the bank, there are strong reasons to believe that this has not been the case. Such reasons include (i) the attributes and professional qualities of the candidates for the board, (ii) the way in which the bank reveals information on the decisions taken by the board and (iii) the way in which decisions are made within the board and the resolutions of disagreements.

First, although the President has complete freedom to choose the members of the board that he is entitled to, he also has an incentive to send a strong signal about the economic responsibility of his decision through the professional attributes of the members he chooses. The selection of members with dubious qualifications, on the contrary, would send a negative signal to economic agents in all sectors of the economy, and would jeopardize the credibility of the government on economic matters. Given this, it is not surprising that the members whom the government has chosen so far have been reputable, well-known professionals in the field of economics with long and outstanding careers in either the public or private sectors. However, appointing members with these attributes makes it less possible for the government to influence their decisions.

The way in which the bank makes the information on the monetary policy decision-making process public also plays an important role in maintaining

${ }^{8}$ Kalmanovitz (2003) also carries out an analysis of the degree of autonomy of the central bank in Colombia and concludes that autonomy is real but limited. 
the independence of the bank ${ }^{9}$. As part of the implementation of the inflation-targeting strategy and the transparency that this strategy requires, since 2007, the bank has made the result of the voting public when there is disagreement among the members of the board. Since the implementation of inflation targeting, one of the main decisions that the board has taken is to either increase or decrease the interbank interest rate (the main instrument of the inflation-targeting policy). Although more information is provided to the public and the government under this scheme, only the aggregate results of the voting are released. In other words, information on how each particular member of the board voted is not provided in the press releases. Only when a decision has been made with complete unanimity, it is possible to infer the individual votes of the board members. What is the effect of this situation on independence? It means that the government is unable to hold the members it appoints, including the Finance Minister, publicly accountable. This situation gives these members, as well as the rest of the board, the opportunity to deviate from the opinions of the government and to act on their own judgments concerning the best policy to support without having to respond individually for their actions.

One additional institutional arrangement that could contribute to the independence of the bank is the way in which decisions are taken and policies implemented within the board. It has been established that any decision taken by the board must be based on a technical document prepared by the relevant staff of the bank (most of the time the Economic Studies Unit or the Monetary and Reserves Unit). Early in the week in which a board meeting is to take place a "pre-board meeting» is held. In addition to the staff members of the bank who prepared the technical document, all the members of the board have attended this meeting, except the Minister of Finance, who is represented by his deputy. The objective of this meeting is to discuss the technical document prepared by the bank's staff and to give the board members a chance to express their views on the technical document. It is important to highlight that no decisions or voting take place in this pre-board meeting. Once in the formal board meeting, there is a discussion of the technical document and if there are divergent opinions among the members of the board, these are presented in terms of the document under consideration. If there is a disagreement, for example, about increasing or decreasing the interest rate and by how much, the board members will vote and the aggregate results are published as described above.

As has been mentioned, although presidential re-election could, in theory, have given the government more influence over the bank's policy decisions, this influence seems not to be as important as it could initially appear once we consider the professional qualities of the appointed members, the way in which

9 See Mejía (2007) for a description of, and the rationale behind, the information released by the bank after the board meetings are being held. 
the bank releases information on the actions of the members of the board in the board meetings, and the process by which the board arrives at its decisions.

Despite the fact that the independence of the central bank was stipulated in the Constitution of 1991, this has not prevented threats to the formal independence of the bank from the government in periods of economic or political turmoil. A recent example of such threats to the independence of the central bank occurred in 2004 when the Colombian peso revaluated by almost 9 per cent against the U.S. dollar. At the time, the President of the Republic publicly asked the bank to control the revaluation by intervening in the market, despite the bank's policy at the time of only participating in the market to reduce the volatility of the nominal exchange rate. As the bank did not respond in the way the executive government desired, the President's office prepared a decree that would have taken away the bank's foreign exchange functions, passing them to the central government. Viewing this as an inappropriate measure, several producer associations advised the government not to pursue this initiative because of the negative consequence it would have had.

Although the Constitution gave the bank independence from the government, the above example illustrates how independence may be changed not only formally (by taking direct action to reduce it through constitutional reforms), but also indirectly, by reducing the sphere of its activity through presidential decrees.

Overall, the Colombian experience with central bank autonomy established through the Constitution of 1991 seems to have been successful ${ }^{10}$. In the period 1992-2008, the inflation rate fell to an average level of 12.5 per cent. In addition, it is the only subperiod in which the trend in the inflation rate is negative. Also, the variability of the rate fell to the lowest level among the four subperiods discussed here, with a standard deviation around the linear trend of 2.9 .

\section{EMPIRICAL APPLICATION: WAS THERE A STRUCTURAL BREAK IN THE EARLY 1990S?}

A few years after the 1991 reform that gave the Colombian central bank a higher degree of independence, there was some debate concerning whether this new institutional arrangement was superior, in terms of reducing inflation, to the earlier arrangements, in particular the Junta Monetaria (Fernández Riva 1996; Meisel 1996). Since the reforms were very recent, it was extremely difficult to analyze whether the evidence was consistent with the hypothesis that the reforms had helped to lower the levels of inflation

${ }^{10}$ For a review of the monetary policy implemented during this subperiod, see Kalmanovitz (2001) and Gómez (2006). Gómez et al. (2002) and Betancourt and Vargas (2008) discuss the implementation of inflation targeting in detail. 
significantly. At present, however, we have a sufficient number of observations to examine this issue using rigorous statistical methods.

In this section, we use quarterly data for the period 1980-2008 to explore the hypothesis of whether there was a structural break in 1991 in the inflation series. If the central bank did in fact make use of the new flexibility that independence gave it to fight inflation, a structural break in the series of inflation should be observed soon after the reform went into effect in $1991^{11}$. We would expect this break in the series as the inflation rate had been increasing, since the early 1980s. We interpret these tests as a necessary condition for determining whether the central bank independence in Colombia had an impact on inflation. The tests we employ cannot tell us whether this effect (if any) is causal. However, the presence of a structural break in the appropriate year in the inflation series would coincide with the strong institutional change that gave the central bank more independence at the beginning of the 1990s.

Figure 4 shows the inflation series and the CUSUM and CUSUM of squares tests (row 2) for the inflation series in Colombia. The reform that established the independence of the central bank in Colombia was adopted in 1991. In addition, in the second column of the first row, the figure shows the residuals of the model behind the CUSUM and CUSUM of squares test; this is a univariate autoregressive model with five lags - AR(5). It is important to point out that if our main hypothesis is correct (i.e. that there was a structural break in 1991), fitting a "well-behaved» model for the entire period (1980:01-2008:04) will be very difficult.

The CUSUM test is based on the recursive residuals of the model. Figure 4, second row (column 1), presents the graphical representation of $R_{m}=$ $\hat{\sigma}^{-1} \sum_{t=k+1}^{m} r_{t}$ for $m=k+1, \ldots, T$; where $r_{t}$ stands for the recursive residual (Maddala and Kim 1999). The straight, dashed lines are the probabilistic bounds for the path of $R_{m}$ under the null hypothesis (the level of the test is 5 per cent). The null hypothesis of no-break is rejected, if $R_{m}$ crosses the boundary. The aim of this test is to detect systematic changes in the coefficients of the model. On the other hand, the CUSUM of squares (second row) plots $S_{m}=\left(\sum_{t=k+1}^{T} r_{t}^{2}\right)^{-2} \sum_{t=i}^{m} r_{t}^{2}$ for $m=k+1, \ldots, T$. This test aims to capture irregular changes in parameters. In a similar fashion to the CUSUM test, the null hypothesis is rejected, if $S_{m}$ crosses the boundary. The boundary in the figure is at the 5 per cent level.

Figure 4 shows that there are some evidence consistent with systematic parameter instability (CUSUM test) in Colombian inflation soon after the new constitution gave the central bank its independence in 1991. The CUSUM of squares tests finds evidence of irregular changes in parameters Colombia, starting approximately in 1986 and ending in 2004. This is not surprising given the high variability of the inflation series at the beginning of

${ }^{11}$ This is not to say that this is the only explanation consistent with the data, but it does constitute a necessary condition. 
FIGURE 4

INFLATION SERIES AND TESTS OF STRUCTURAL BREAK IN THE INFLATION SERIES, 1980-2008
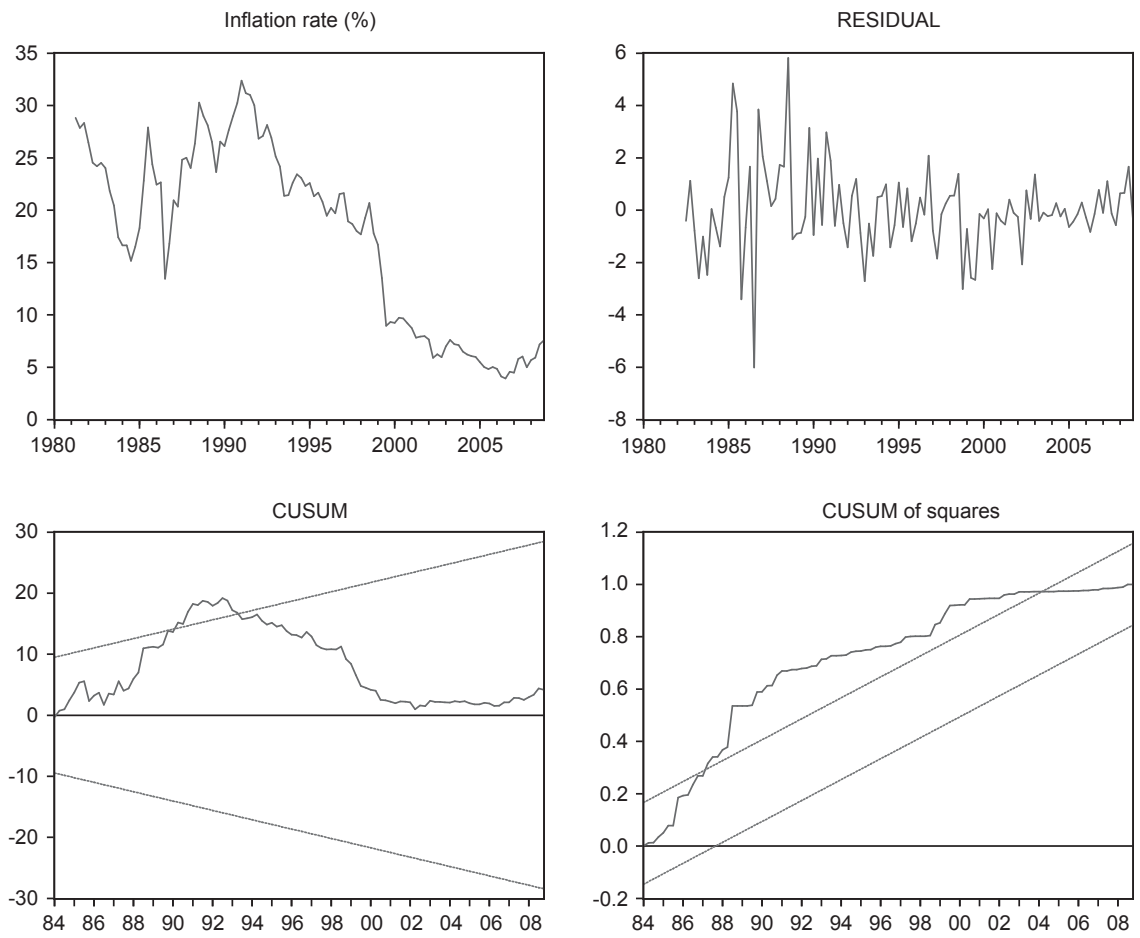

Notes: To obtain information for this figure, we estimate univariate AR(5) models for the quarterly series of inflation for the period 1980-2008. The first row presents the CUSUM test, the second the CUSUM of squares test and the third plots the residuals of the model. The reform to the central bank in Colombia took place in 1991. Dashed lines represent boundaries for the tests at 5 per cent level. We cannot reject the null hypothesis of no breakpoint at 1992q1 for Colombia using a Chow test $(F, P$-value $=0.2879)$.

the sample (see row one, column one). Moreover, the residuals of these models (Figure 4, row one, column two) indicate the bad fit of the model before the central bank independence (1991). In general, several other models that were estimated have the same problem: either a good or bad fit before the reform and a good or bad fit after the reform. This indicates that no single model can accommodate the dynamics of inflation before and after reform. It is also important to mention that if the model is not adequate in terms of the assumptions about the properties of the error term, inference about structural breaks might not be valid.

Although not all the tests show consistency with the hypothesis that there is a break in the series of inflation, those that which are consistent are too 
precise to be simply disregarded. This, in addition to the dramatic change in the trend of inflation after the reform, the reduction in the variance in the series, and results from other studies such as Otero and Ramirez (2006), seems to indicate a structural break shortly after the establishment of central bank independence. Although it is possible that some other factors caused the reduction in inflation, the break in the series is consistent with the hypothesis that the introduction of an independent central bank (and the policies that is able to carry out) is an important determinant of the inflation rate.

\section{CONCLUDING REMARKS}

In this paper, we present a summary of the results of four phases of the history of the Banco de la República and the institutional arrangements that created them. It is clear that the first period in the history of the bank (19231951) has the best outcome from the point of view of the average level of inflation. However, in terms of instability, the fourth period (1992-2008) has the lowest standard deviation around the trend. Although the fourth period has the third highest level of inflation, this period lasted only 18 years and the inflation rate when it started was high. The trend in the inflation rate, nevertheless, is negative and statistically significant. Thus, from a historical perspective, the best results in terms of lower inflation were obtained with an independent central bank pursuing autonomous objectives. The worst results in terms of inflation are those for period three (1964-1991), which was characterized by a dependent and unorthodox central bank. Although causality is hard to establish in this case, the Colombian experience seems to suggest that central bank independence and a clear mandate render the best outcome in terms of inflation.

For the period 1992-2008, the paper also discusses recent threats to the independence of the central bank. These threats come either from direct suggestions by the government on which policies the bank should follow, or indirectly through political changes (e.g. presidential re-election), which give a re-elected government the opportunity to appoint four members of the board. The apparent loss of independence caused by the presidential re-election, however, seems to have been balanced by the government's incentives to appoint prestigious economists as board members as well as by the way decisions are taken within the board, and through the procedures followed for releasing information to the public in terms of how the board members vote.

\section{REFERENCES}

Alesina, A. (1988): «Macroeconomics and Politics», in S. Fischer (ed.), NBER Macroeconomics Annual 1988. Cambridge: MIT Press, pp. 13-52.

BAde, R., and Parkin, M. (1985): "Central Bank Laws and Monetary Policy». Unpublished manuscript, University of Western Ontario, Canada. 
Berger, H.; De Haan, J., and EijfFinger, S. (2001): "Central Bank Independence: An Update of Theory and Evidence». Journal of Economic Surveys 15, pp. 3-40.

Betancourt, R., and Vargas, H. (2008): «Encajes Bancarios y la Estrategia de Inflación Objetivo». Borradores de Economía no. 533. Bogotá: Banco de la República.

Bonnet, J., and Vargas, H. (1994): «La Independencia de la Banca Central en América Latina». Borradores de Economía no. 2. Bogotá: Banco de la República.

Carstens, A., and JÁcome, L. (2005): «Las Reformas de Los Bancos Centrales Lationamericanos: Avances y Desafíos». El Trimestre Económico LXXII, pp. 683-732.

Crowe, C., and Meade, E. (2008): "Central Bank Independence and Transparency: Evolution and Effectiveness». IMF Working Paper. Washington D.C.: International Monetary Fund.

Cukierman, A. (2008): "Central Bank Independence and Monetary Policymaking Institutions - Past, Present and Future». European Journal of Political Economy 24 (4), pp. 722-736.

Cukierman, A.; WebB, S. B., and Neyapti, B. (1992): «Measuring the Independence of Central Banks and Its Effects on Policy Outcomes». The World Bank Economic Review 6, pp. 353-398.

Daunfeldt, S., and De Luna, X. (2008): «Central Bank Independence and Price Stability: Evidence from OECD Countries». Oxford Economic Papers 60, pp. 410-422.

Deane, M., and Pringle, R. (1994): The Central Banks. New York: Homish Hamilton.

Echeverri, L. (1991): «Free Banking in Colombia, 1865-1886». Georgia: University of Georgia, PhD dissertation.

EijfFinger, S., and De HaAn, J. (1996): «The Political Economy of Central-Bank Independence». Special Papers in International Economics no. 19. Princeton, NJ: Princeton University.

Fernández Riva, J. (1996): «La Torre de Marfil». Carta Financiera, Bogotá. Bogotá: Asociación Nacional de Instituciones Financieras - ANIF, pp. 60-61.

Giraldo Palomino, A. F. (2007): Aspectos Institucionales de la Banca Central en Colombia 1963-2004: La Junta Monetaria y la Junta Directiva del Banco de la República. Bogotá: Pontificia Universidad Javeriana.

Gómez MejíA, A. (1997): «Sobre la Independencia del Banco de la República». Estudios Gerenciales 66, pp. 71-84.

Gómez, J. (2006): «La Política Monetaria en Colombia». Borradores de Economía no. 394. Bogotá: Banco de la República.

Gómez, J.; Uribe, J., and Vargas, H. (2002): "The Implementation of Inflation Targeting in Colombia». Borradores de Economía no. 202. Bogotá: Banco de la República.

Grilli, V.; Masciandaro, D., and Tabellini, G. (1991): "Political and Monetary Institutions and Public Financial Policies in the Industrial Countries». Economic Policy 6, pp. 342-392.

Grove, R., and Alter, G. (1986a): «Memorando Sobre la Reorganización del Banco de la República». Banca y Finanzas 2, pp. 28-31.

Grove, R., and Alter, G. (1986b): «Deficiencias en la Estructura de la Banca Central Colombiana». Banca y Finanzas 2, pp. 21-27.

Grupo De Estudios De Crecimiento Económico (GRECO) (1999): «El Desempeño Macroeconómico Colombiano - Series Estadísticas (1905-1997), Segunda Versión». Borradores de Economía no. 121. Bogotá: Banco de la República.

GutiÉRrez, E. (2003): «Inflation Performance and Constitutional Central bank Independence: Evidence from Latin America and the Caribbean». IMF Working Papers. Washington D.C.: International Monetary Fund. 
de HaAn, J., and KooI, W. (2000): «Does Central Bank Independence Really Matter?: New Evidence for Developing Countries Using a New Indicator». Journal of Banking \& Finance 24 (4), pp. 643-664.

DE HAAn, J., and Sturm, J. E. (1992): «The Case for Central Bank Independence». Quarterly Review 182, pp. 305-327.

Hayeк, F. A. (1976): The Denationalization of Money: an Analysis of the Theory and Practice of Concurrent Currencies. Albuquerque: Transatlantic Arts.

JÁcome, L. (2001): «Legal Central Bank Independence and Inflation in Latin America during the 1990s». IMF Working Papers. Washington D.C.: International Monetary Fund.

Jácome, L. I. (2008): «Reformas Institucionales en la Banca Central LatinoAmericana», in Papers and Proceedings - Reformas Institucionales en la Banca. Washington DC: International Monetary Fund.

Jácome, L. I., and Vázouez, F. (2008): «Is There Any Link between Legal Bank Independence and Inflation? Evidence from Latin America and the Caribbean». European Journal of Political Economy 24, pp. 788-801.

Kalmanovitz, S. (2003): «El Banco de la República como institución independiente», in S. Kalmanovitz (ed.), Ensayos sobre Banca Central: comportamiento, independencia e historia, 51-70. Bogotá: Grupo Editorial Norma y Banco de la República, pp. 51-70.

Kalmanovitz, S. (2001): «El Banco de la República y el Régimen de Meta de Inflación». Borradores de Economía no. 193. Bogotá: Banco de la República.

Maddala, G. S., and Kim, I. (1999): Unit Roots, Cointegration, and Structural Change. New York: Cambridge University Press.

Meisel, A. (1992): «Free Banking in Colombia», in K. Dowd (ed.), The Experience of Free Banking. London: Routledge, pp. 93-102.

Meisel, A. (1996): «Autonomía de la Banca Central e Inflación: la Experiencia Colombiana, 1923-1995». Borradores de Economía no. 49. Bogotá: Banco de la República.

Mejía, D. (2007): La Publicación de las Minutas de la Junta Directiva del Banco de la República: Un Paso Adicional Hacia Una Mayor Transparencia. Bogotá: Departamento de Comunicación Institucional, Banco de la República.

Otero, J., and Ramírez, M. (2006): «Inflation Before and After Central Bank Independence: the Case of Colombia». Journal of Development Economics 79, pp. 168-182.

Restrepo, J. M. (2000): «Central Bank Independence and Inflation: the case of Colombia, 1924-1998». Revista de Economía del Rosario 3, pp. 37-63.

Rockoff, H. (1974): «The Free Banking Era: A Reexamination». Journal of Money, Credit and Banking 6, pp. 141-167.

Rogoff, K. (1985): «The Optimal Degree of commitment to an Intermediate Monetary Target». Quarterly Journal of Economics 2, pp. 1169-1189.

Rolnick, A. J., and Weber, W. E. (1983): "New Evidence on the Free Banking Era». American Economic Review 5, pp. 1080-1091.

Sanz De Santamaría, C. (1965): Una época difícil. Bogotá: Tercer Mundo.

Sargent, T. J., and Wallace, N. (1981): «Some Unpleasant Monetarist Arithmetic». Federal Reserve Bank of Minneapolis Quarterly Review 5, pp. 1-15.

Schuler, K. (1992): «The Experience of Free Banking», in K. Dowd (ed.), The Experience of Free Banking. London: Routledge, pp. 1-6.

Sechrest, L. J. (1993): Free Banking: Theory, History, and a Laissez-Faire Model. Westport, CT: Quorum Books.

Urrutia Montoya, M., and Caballero Argáez, C. (2006): Historia del Sector Financiero en Colombia en el Siglo XX. Bogotá: Editorial Norma.

White, L. H. (1984): Free Banking in Britain: Theory, Experience and Debate 1800-1845. London: Cambridge University Press. 